\title{
Reflections on the characters of Dr Rieux and Fr Paneloux in Camus' The Plague in a consideration of human suffering during the COVID-19 pandemic
}

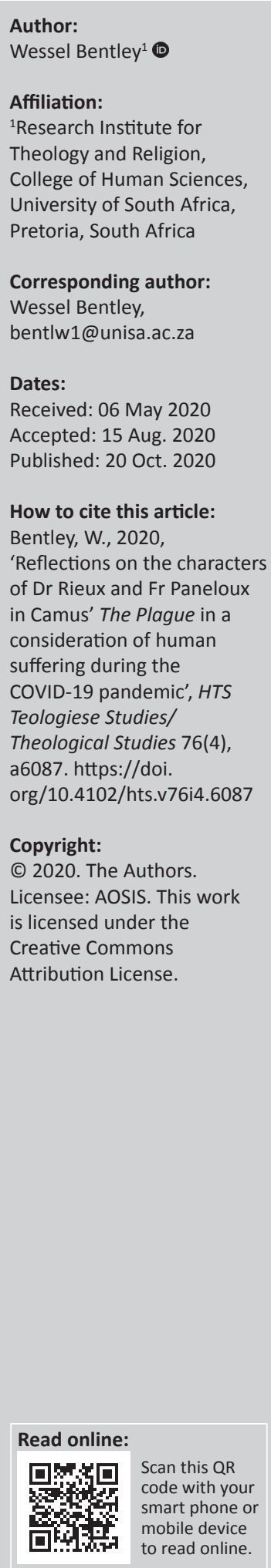

During the COVID-19 pandemic of 2020, one is drawn to engage with texts that deal with the topic of human suffering. Two texts will be considered in this article. The first is the novel The Plague by Albert Camus, and the second is the Bible. Two characters in Camus' work will be discussed as representatives of different theological and scriptural responses to the issue of widespread human suffering. Following a literary analysis research methodology, this article argues that Christian responses to the COVID-19 pandemic are not dissimilar to the perspectives held by Dr Rieux and Fr Paneloux. Theodicy is engaged with either a perspective that questions the Divine in the light of the suffering of the innocent or a perspective that subjects itself to a state of surrender to 'the God who knows best'. The article then offers a third perspective, one held by Camus himself, suggesting that the question of theodicy could be reimagined from the notion of the absurdity of life.

Contribution: This article provides a theological reflection on common Christian responses to the COVID-19 pandemic. It uses Camus' novel, "The Plague" as a backdrop to differentiate between a deistic and a science-faith approach to suffering.

Keywords: theodicy; COVID-19; Camus; La Peste; The Plague.

\section{Introduction}

\begin{abstract}
From now on, it can be said that the plague was the concern of all of us. Hitherto, surprised as he may have been by the strange things happening around him, each individual citizen had gone about his business as usual, so far as this was possible. And no doubt he would have continued doing so. But once the town gates were shut, every one of us realized that all, the narrator included, were, so to speak, in the same boat, and each would have to adapt himself to the new conditions of life. Thus, for example, a feeling normally as individual as the ache of separation from those one loves suddenly became a feeling in which all shared alike and, together with fear, the greatest affliction of the long period of exile that lay ahead. (Camus 1991:67)
\end{abstract}

It is thus that Albert Camus in his novel, The Plague, ${ }^{1}$ describes the change in people's lived experience following the onset of the plague in Oran, a small coastal city in Algeria. These words are an eerie portent of the experiences of people throughout the world in 2020, as entire countries instituted different forms of social lockdown in response to the COVID-19 pandemic, arguably one of the greatest challenges faced by humankind in recent history. At the time of writing this article, over 4 million confirmed cases had been reported globally, with the number of those having succumbed to the virus nearing 300000 . There is no foreseeable end in sight to the rising number of those infected and those dying from this disease. Although hopeful of a medical breakthrough, the global community is set to navigate uncharted waters for the next few years (at least).

How does one respond to human suffering on this scale? From a church-practitioner's perspective, it is a situation that either draws people closer to God in search of protection or causes them to give up on God altogether. Needless to say, the theological responses to this global pandemic have been varied. At one end of the theological spectrum, one finds the spiritualising of the virus, equating it to the warning signs professed by the biblical prophets and signalling God's impending judgement on the earth. ${ }^{2}$ Along with calls to repentance, there have also been proclamations of spiritual

\footnotetext{
1.In the original French, the title of the novel is La peste. The novel has been translated into a number of languages, and The Plague is the title of the English translation.
}

2.Examples of these positions will be provided later in the article. 
victory, using Scripture to suggest that the faithful are somehow protected from the virus. At the other end of the spectrum, one finds theology engaging with science. Here, whilst questions about suffering, pestilence and God's role in all of these are indeed considered, God is not seen as the primal causer of the virus, but is instead placed alongside and in solidarity with all who are living through these difficult times. This article investigates recourse to Scripture in such times against the backdrop of the novel The Plague by Albert Camus. Two characters, namely Dr Rieux and Fr Paneloux, stand as representatives of the two perspectives just identified.

\section{The Plague: The context of the novel}

The Plague by French philosopher and journalist Albert Camus (1913-1960) was published in 1947, having been written as a reflection on the Second World War and, in particular, the German occupation of France. The novel was written as an anti-Nazi work, and in it, Camus uses allegory to equate the occupying Nazi forces (and the regime that they represented) with the plague-carrying rats dying on the streets of Oran and bringing the dreaded disease to the local population (Monasterio 1999:217). Whilst acknowledging the allegorical nature of this novel, in this article I do not wish to engage with its socio-political narrative, but rather to focus on how Camus uses the characters of Dr Rieux and Fr Paneloux (as socially reputable leading thinkers, albeit holding seemingly irreconcilable perspectives), who chart the way forward in asking questions about meaning, suffering and, ultimately, God's role in it all.

In The Plague, Camus describes the pestilence as contagious, infecting and affecting every person who comes into contact with it. Nobody seems to be spared, and so, as an act of social responsibility, this community is quarantined in order to limit the spread of the disease beyond its boundary. As people deal with their new reality, some are found to be in denial, some rebel against the strict social measures, some simply accept their state of being, whilst others deliberately fight the scourge of disease by caring for the stricken. In the midst of this ordered chaos, we find a medical doctor, Dr Rieux, doing his best to fight the spread of the disease. At the same time, the local priest, Fr Paneloux, theologises the epidemic, initially describing it as a sign of God's wrath and vengeance, but later adopting a theological position that requires greater humility of him and his followers. One of the main lines of tension in the novel is not only between Rieux and Paneloux, representing the apparent conflict between science and religion, but also between the open-ended questioning of mystery versus the misguided certainty inherent in some expressions of institutionalised religion.

It is no secret that Camus' personal view of the Christian faith was initially somewhat negative (Monasterio 1999:215). This is evident in this novel in the portrait he paints of both Rieux, especially in his conversations with characters such as Tarrou, ${ }^{3}$ and Paneloux as he leads his frightened congregation through troubled times. Camus' engagement with the subject of Christianity and suffering receives detailed consideration in Whistler (2018), to which the reader is referred. Nonetheless, it is worth noting that Camus was not completely dismissive of the Christian faith, becoming more sympathetic towards it as he came into closer contact with the anti-Nazi underground resistance movement (Monasterio 1999:215). It may be argued that through the development of Paneloux's theological perspective and Rieux's increasing incorporation of the metaphysical into his purely scientific approach, Camus indicates the apparent slowness with which religion responded to Nazism. Whilst recognising the validity of the Christian faith, Camus seems to describe it as a 'late comer' to any crisis, whether it be the Nazi occupation of Europe or the outbreak of an epidemic in a bustling city.

Believing Christianity 'to have betrayed its founder' (Ballard 1975:423), Camus showed great interest in Jesus. Ballard (1975:423) states that to Camus, Jesus is a profound example of human existence in the absurdity of life: Jesus as 'rebel' remains at the centre of the Christian faith. Ballard further asserts that to Camus, it was the Christian belief in (perhaps overemphasis on) the resurrection (negating Jesus' rebellion against the absurd) and the Kingdom beyond (not as an immanent possibility or reality) that destroyed what Jesus actually stood for and replaced him with an iconic figure, devoid of human fragility, worshipped by Christians. The words in brackets above are important, as without them the statement may be understood to mean that Camus rejected some of the fundamental teachings of the Christian faith. Yet what Camus really struggled against was Christianity's apparent fixation with notions such as 'hope', 'afterlife' and eschatological victory, which prevented it from being fully present in the chaos, suffering and unfairness of the present. To Camus, Jesus was truly present in his context, calling his followers to do the same, but somehow the Christian belief shifted from being present in real existential crises to becoming a faith based on transcendental and metaphysical presuppositions.

In The Plague, Camus challenges Christianity's self-professed moral superiority and instead proposes a moral philosophy that is not founded on religion (Whistler 2018:52). That said, the moral and theological positions embodied in Dr Rieux and Fr Paneloux manifest in the theological responses to the COVID-19 outbreak that we have witnessed so far.

\section{Father Paneloux and religious certainty}

The first form of theological response that we will discuss entails theologising the virus, by suggesting that it is either a warning from or a deliberate act of judgement on the part of God. In The Plague, Fr Paneloux begins a sermon to his congregation with the words: 'Calamity has come on you, my brethren, and, my brethren, you deserved it' (Camus 1991:94). Paneloux then goes on to describe the plague as being similar to the plagues sent by God in order to liberate 
God's people from Pharaoh's hand (Camus 1991:95). However, in the sermon, Paneloux contradicts himself as to the cause of the suffering. On the one hand, he states that the plague was not part of God's will, but arose as an inevitable consequence of human evil (Camus 1991:94), whilst on the other hand, he warns the congregation that once God's hand was set against them, not even science would be able to come to their rescue (Camus 1991:96). In closing, Paneloux then cites the example of a similar outbreak in Abyssinia, where Christians used the opportunity to interpret their suffering as a call to repentance and eternal life (Camus 1991:98).

With the outbreak of COVID-19, it did not take long for theological and biblical pronouncements to be made along similar lines to Fr Paneloux's first sermon. Secular media picked up on these pronouncements, which appeared widely on social media (Kettley 2020) and did not do the Christian faith any favours through the way in which they reported them. Popular pronouncements ranged from citing Matthew 24:7, where Jesus speaks about the signs of the end times, to 2 Chronicles 7:13, where God speaks to Solomon, stating that if signs like the absence of rain, a plague of locusts or a plague afflicting people were experienced, these should serve as motivations for people to turn to God in repentance. When such prayers were offered, God would hear them, forgive the people and remove their affliction.

With reference to the 2 Chronicles reading, additional comments were made on social media, linking the reference to the lack of rain to the drought and subsequent wildfires experienced in Australia (2019-2020), and pointing out both the plague of locusts as experienced in East Africa (2020) and the global COVID-19 outbreak, citing all of these as signs of God's anger. These signs indicate that the world should repent, after which God would restore everything to glory through the Second Coming of Christ or at least to a way of life that is prosperous, peaceful and whole.

In addition, popular faith leaders made their own pronouncements. Pastor Kenneth Copeland (2020b) claimed to have received a message from God, proclaiming that the outbreak would be over sooner than expected, conditional on people's return to God. He further used Galatians 3:13 to 'execute judgement over COVID-19', equating it to the work of Satan, and hence placing it in direct opposition to the will of God (Copeland 2020a). Although I consider Copeland a problematic example of a Christian response, mainly on the basis of fundamental theological differences, his message seems representative of a widespread theological response to the outbreak. Some African Pentecostal movements have demonstrated a similar response, referring to texts such as Leviticus 26:14-16, Deuteronomy 28:15 and 22 and Isaiah 26:20-21, describing COVID-19 as a curse, which necessitates immediate repentance and submission to God. Prophet Bushiri, a popular religious figure in South Africa, described the virus as a sign of the end times and stated that it would target certain individuals; once the 'demonic virus' had claimed all its victims, it would disappear (Citizen Reporter 2020). He further stated that Christians could expedite the process by standing up against the pandemic and claiming their victory in faith. Many religious leaders have ignored calls for physical distancing and have encouraged their congregations to continue worshipping, asking their congregants to believe that the virus could be defeated through their faith in God (Wilson 2020). It is hardly surprising, then, that some have openly protested against physical distancing measures and held on to their faith as a form of protection against the virus (see Mudde 2020).

From an academic theological perspective, one may judge these responses to be rather thin in theological substance, but I would like to argue that they should not be underestimated, nor should the profound influence that faith leaders have in the theological engagement of congregations with their lived experiences be downplayed. This kind of theological language is common as Christians try to make sense of this new crisis.

When one evaluates these responses (including that of Paneloux), one finds that they are based on two presuppositions. The first is that history can be interpreted within the scope of a fixed and definite (read 'biblical') timeline, and the second is that all lived experience is to be understood within the tension that exists between the sin and redemption narrative of Scripture.

The first of these presuppositions is reflected in the composition of the biblical books. From a literalist perspective, the book of Genesis describes the creation and beginning of all things, whilst the book of Revelation leads the reader to what is understood to be the end of this creation. Everything between these two points is then experienced as existential reality. Along with this reading of Scripture and interpretation of life, comes a metaphorical three-tiered universe, composed of heaven, hell and earth. How does one make sense of suffering such as the plague or COVID-19 in light of this view of life, Scripture and the universe? One may deduce that within this closed system, where life is experienced within a limited predetermined timeframe, every aspect of life needs to be interpreted spiritually. All that is good, prosperous and beneficial for an abundant life is interpreted as coming from God and must therefore be good. Everything that is hurtful and undermines the goodness of life or causes suffering originates either from God (as an act of warning or punishment) or from the devil, who seeks to spoil God's gift of life. It must be stated that although the pastors mentioned above and those who adhere to this perspective profess to live in the Word of God, their level of critical exegesis of their quoted portions of Scripture leaves a lot to be desired. Texts are cited without due consideration for their historic, narrative or cultural context and quoted as being the proverbial voice of God in our current context. It is interesting that none of the Christian voices mentioned refers to the book of Job, which in essence calls into question the second of the two presuppositions. 
The second presupposition, which interprets life within the tension of the sin and redemption narrative of Scripture, sees all life experience as either stemming from sin or leading to some form of redemption. The book of Job interrogates this assumption by asking why 'bad things happen to good people'. Job's wife and friends all uphold the perspective proclaimed by Fr Paneloux (and the listed examples). They argue that Job must have sinned, hence his suffering. The afflictions he faces could be seen either as judgement by God or as a punitive measure to get Job back onto the right track. The point of the book of Job is that suffering should not be interpreted in this light at all. Instead, there is an element of absurdity to life, and things like illness, poverty and suffering have no metaphysical origin. They do not colour in the narrative between the beginning and end drawing on the notions of sin and redemption. There is no apparent transcendentally afflicted sense that is imposed with the experience thereof, but that as part of life, these situations of affliction are experienced existentially and randomly. That said, it does not mean that suffering, illness and the like should prevent a person from raising his or her eyes towards heaven and asking questions about divine justice. Job does so with justification, but the eventual answer he receives does not place his experience within the domain of the fixed beginning-end biblical narrative or within the tension between sin and redemption. Instead, God's answer points to the scale, mystery, randomness and inevitability of life, leaving Job reassured that he is not the recipient of some form of misaligned divine (or cosmic) justice.

Is Fr Paneloux then a false prophet? Do leaders like Copeland, Bushiri and others preach a message incongruent with the Christian gospel? Fr Paneloux has good intentions, ${ }^{4}$ but his initial sermon brings fear, not comfort to his parishioners. This sermon places them within the dichotomies of beginning and end, sin and salvation and does not help them to identify any practical way either to prevent themselves from becoming infected or to care for the afflicted. Paneloux does eventually enter the fight against the plague, but maintains his theological position. That is, until a pivotal moment in the novel, when Paneloux and Rieux together witness the death of a young boy, Jacques Othon, the son of the city's magistrate. The death in this prominent family indicates that the disease is not confined to the marginalised in society, but crosses all boundaries, including socio-economic and so-called 'class' differentiations. Emotions between Rieux and Paneloux spill over, with the priest, in the light of this existential crisis, having to ask questions about his own theological position.

His biblical beginning-end, sin-salvation paradigm does not offer sufficient answers. When confronted with the absurdity of life, Paneloux's perspective can only offer silence or at best a placatory rhetoric: 'Perhaps we should love what we do not understand' (Camus 1991:218). The hermeneutic approach taken by Paneloux and our COVID-19 examples cannot do better than this. It removes personal responsibility from the individual and the community, limiting their response to gazing heavenward, asking what needs to be done to appease God so that their suffering may cease. It perpetuates the notion that there is no freedom in the progression of history, but that in this form of religion and biblical use, we find an overt expression of humanity's slavery to metaphysics (Ballard 1975:423).

This form of religion and biblical use is both easy and comfortable when practised and proclaimed from a distance, but is challenged when the 'preacher' comes face-to-face with suffering - when the plague lands on one's own proverbial doorstep. Father Paneloux realises his theological shortcomings and preaches a second sermon. The difference in theological certainty is significant. In delivering the first sermon, Paneloux spoke with certainty, with authority and conviction; however, his delivery of the second is cautious and humble. The narrator (Dr Rieux) tells us (Camus 1991):

He spoke in a gentler, more thoughtful tone than on the previous occasion, and several times was noticed to be stumbling over his words. A yet more noteworthy change was that instead of saying 'you' he now said 'we'. (p. 222)

In a cruel twist of irony, Fr Paneloux himself falls ill. We do not know for certain whether he has contracted the plague, but Camus draws out the irreconcilable tension between Paneloux's theological position and the experience of suffering. What is Paneloux to do? Should he abide by the message of his first sermon? If so, then he has drawn down God's wrath and judgement upon himself. If he abides by his second sermon, then he should simply accept suffering as part of God's will for his life. Paneloux appears to choose the second option, dying with a crucifix in his hands and refusing medical treatment (Monasterio 1999:216). He accepts God's will, surrenders and in doing so (in his eyes) becomes a martyr, dying alongside those who have succumbed to the plague (Monasterio 1999:229).

Before we discuss Paneloux's position any further, let us now turn to Dr Rieux.

\section{Dr Rieux and the problem of innocence}

At the start of the novel, Dr Rieux's position appears to be the antithesis of Fr Paneloux's. Rieux notices rats dying in the streets, but does not pay them much heed. It is only later, when the number of dead rats increases and the first few cases of illness amongst people are reported that Rieux makes the connection, realising that an epidemic is afoot (McWilliams 1990:14). He sees the situation for what it is, namely an illness carried by rats and transmitted to human beings, having lethal consequences. The doctor accepts this as a natural occurrence, ${ }^{5}$ and hence when Fr Paneloux preaches his first sermon, does not take the priest's perspective too seriously. His focus is on the spread of the disease and how to limit its effect. He treats the ill with product of the human will, of a vigilance that must never falter' (Camus 1991:253). 
compassion, instituting protocols that may inconvenience society, but are for their own good.

As the plague spreads and the magnitude of the suffering becomes evident, Tarrou probes Dr Rieux, trying to understand how the doctor makes sense of it all. Rieux is not immune to thinking about life in metaphysical terms. The plague certainly seems to be unfair, affecting people indiscriminately. How do you rationalise injustice (Sharpe 2014:173)? Paneloux's sermon certainly attempts to do so, but fails. Paneloux, who is supposed to be the embodiment of a good and godly person, fails in answering the question of life's absurdities. Doctor Rieux's attempt to understand the plague operates on two levels. On the first level he accepts the plague as nothing more than a natural occurrence. On the second level, he struggles with the notions of right and wrong, fairness and unfairness, certainty and doubt as put forward by the people who should have the metaphysical answers. In his view, Fr Paneloux contributes very little to fighting the plague, whilst he, a medical doctor, seems to be the one who is truly carrying out acts of mercy. This dilemma is evident in the conversation he has with Tarrou (Camus 1991):

\footnotetext{
'In short', Tarrou said simply, 'what interests

me is to know how one becomes a saint'.

'But you don't believe in God'.

'Precisely. Can one become a saint

without God: that is the only concrete

question that I know today'. (p. 255)
}

Tarrou's question puts words to Rieux's inner struggle, to the point where he confesses (pardon the pun) (Camus 1991):

But, you know, I feel more fellowship with the defeated than with the saints. Heroism and sanctity don't really appeal to me, I imagine. What interests me is being a man. (pp. 255-256)

When Rieux and Paneloux witness the death of young Jacques, Rieux confronts Paneloux's metaphysical presuppositions. When Paneloux offers the platitude of loving what we don't understand, Rieux objects, stating (Camus 1991):

No, Father. I've a very different idea of love. And until my dying day I shall refuse to love a scheme of things in which children are put to torture. (p. 218)

It is not that Rieux has forgone love, or justice, or hope, but for him these metaphysical notions should be grounded in the existential realities of the present. ${ }^{6}$ It is not that he is an atheist, but his concept of God needs an incarnation in which God, too, is a victim and suffers alongside the creatures whom He loves (Ballard 1975:420). This theme comes to the fore in another of Camus' works, The rebel (Camus 1992):

So the history of metaphysical revolt cannot be confused with that of atheism. From one angle, it is even identified with the contemporary history of religious sentiment. The rebel defies more than he denies. Originally, at least, he does not destroy

6.Rieux's dilemma seems to give voice to Camus' own struggles of finding a religious reason for the suffering of the innocent. See Camus (1950:212-213) and Monasterio (1999:218)
God, he simply talks to him as an equal. But it is not a polite dialogue. It is a polemic animated by the desire to conquer ... When the throne of God is overthrown, the rebel realizes that it is now his own responsibility to create the justice, order and unity he sought ... (p. 23)

Although Rieux knows that he is fighting a losing battle, that he will never be able to eradicate all disease and all suffering, it is his duty in this life to take responsibility and to do the best he can to love his neighbour. Paneloux's hope does not make sense to Rieux, because it does not entail any personal responsibility, but instead wishes for a divine intervention devoid of any human participation.

Now to turn to some thoughts in response to COVID-19. Although it may not seem as if Rieux occupies a theological position, I would like to argue that he in fact does, and that it manifests in several theological expressions. The first of these is to be found in reflections presented by the esteemed New Testament scholar, N.T. Wright. Wright (2020) reflects on the COVID-19 outbreak, stating that it is natural for people to ask, 'Why is God doing this to us?'. Like Paneloux, they try to answer this question by identifying a causal mover for their experience of suffering. Someone needs to be blamed and for many people, the natural scapegoat is God. Wright (2020) goes on to say that the theological interpretation of suffering as divine punishment, as a warning or as a sign may offer the easiest answers, but he labels these as 'silly'. Instead of asking the question: 'Who?', Wright suggests that we should rather ask an open-ended 'Why?' It is an openended question, for it does not lead to a single, definitive answer, but gives voice to an existential crisis in the face of the enormity of this situation. This, to Wright (2020), is what it means to lament. 'Lament is what happens when people ask "Why?" and don't get an answer'. We need to note that Wright's definition differs from that of Fr Paneloux, for Paneloux's sermon already assumed an answer, manifested in the beginning-end, sin-redemption paradigms. To Wright, there may not be an answer from above, for God will not respond with a suggestion that suffering is divinely sent for the purpose of formation.

Wright (2020) turns to the Psalms (e.g. Ps 10, 13, 22, 88 and 89 ), giving examples of prayers of lament that do not necessarily elicit answers. From the bottom up, people ask questions, and perhaps they start off where Paneloux did, viewing God as the causal mover. In these expressions of lament the Psalmists, without exception, come to the conclusion that God is not the instigator of their suffering, but is the one who draws alongside them in their experience of suffering. In the absurdity of life, God empathises with creation. God is moved and laments alongside creation. Wright (2020) then concludes his argument by stating that the Christian vocation is not endowed with the ability to explain the suffering experienced in the world, but that Christianity facilitates a process of lament and mourning where the possibility of healing and restoration become actualised in the person's 
fellowship with God, leading to new opportunities for acts of kindness, scientific understanding, hope and wisdom.

Thomas Oord (2019), who wrote a book on theodicy entitled, God can't: How to believe in God and love after tragedy, abuse, and other evils, takes Wright's view a bit further. Although Oord (2020) agrees with Wright's explanation of lament, he cites 1 Peter 3:15, arguing that whilst Christians lament, we should also try to identify what God is doing in response to suffering. God's response is love, but it is the kind of love that Rieux, not Paneloux, holds on to. To Oord (2019:148-158), Christ is the revelation of God's selfless, participatory love, but also calls His followers to participate with God in creation in works of compassion, love and care. These are practical expressions of God's work in creation, which is not divorced from science, knowledge or human participation, but in which all of these are infused.

Wright and Oord engage with Scripture not from the premise of a fixed beginning - end or sin - redemption paradigm, but from the perspective that God journeys within creation in an open and dynamic relationship with it (not to be confused with pantheism), which in turn requires a history open to possibilities, absurdities and human participation. Writing from a place of loss - not the COVID-19 pandemic, but the loss of his son - Abraham (2017) draws from the book of Job, stating:

The fact that we do not have complete explanations does not for a moment entail that we do not have good partial explanations. Half a theological loaf is better than no bread at all. (p. 83)

We can only know what we know, and therefore, as we engage with our lived experience by means of science, perception, language and so forth, we can offer two conjoint responses, namely vocalising our lament whilst at the same time taking the responsibility to participate in acts of compassion, love and, where possible, healing.

\section{Reality as the absurd: Another approach to theodicy}

COVID-19 is an absurd reality. It is natural - as natural as the plague that Dr Rieux encounters - but what makes it absurd is the effect it has on our experience of life. Besides scenes from all over the world of empty highways, nationwide lockdowns and suspended school and sporting activities, we have to come to terms with the fragility of life and the possibility that a virus, a microscopic entity, has the potential to change our lives dramatically for the foreseeable future. To the Panelouxians, the absurd is expected, for their reading of Scripture dictates the way history is destined to play out. The end is to be found in destruction and suffering, which gives birth to eternal life; it is divorced from full presence in the existential crisis of the moment. It does not answer the question of the suffering of the innocent. When faced with this aspect of the problem of suffering and evil, a particular form of logic is employed, reliant on apologetics to defend a metaphysical presupposition that may not be congruent with who God is or what God reveals (Ledwith 1976:669).
This position does not defend God, but it defends an idea of God. It does not struggle for the benefit of God's integrity, but for the spiritual integrity of the believer. If this is true, then Dr Rieux's critique is fitting (Camus 1991):

Paneloux is a man of learning, a scholar. He hasn't come into contact with death; that's why he can speak with such assurance of the truth, with a capital T. (p. 126)

Whilst Rieux himself struggles with the absurdity of life, he employs logic and reason, using these as his tools to become an activist against the evils of this world. He sees suffering at close quarters, and this makes him unable to depend on romanticised ideals of transcendental justice. Rieuxians present an understanding of the absurd as the platform where the gift of life can be exercised responsibly, existentially and in participation with the divine (Whistler 2018):

The kind of transcendence that Camus depicts does not appeal to anything outside this world, it appeals precisely to this world as something powerful, beautiful and incomprehensible, that will outlive us, but that we are part of, and will continue to be after we are dead. (p. 57)

Rieuxians appeal for an honest and real response. Their approach to Scripture not only leads them to ask the unanswered question 'Why?' but also invites active and responsible participation in doing our best to make life good. Life at times is good and of this we should not lose sight. At the same time, life also has moments of tragedy. We view tragedy as the absurd, because it does not match our idealistic expectations of life. Instead of giving up on life, Camus' writing and a Rieuxian engagement with Scripture encourage us to live life to the fullest, even in the midst of all of life's absurdities (McWilliams 1990:13).

Perhaps the end of the novel offers the most prophetic pronouncement on life. Although the plague seemed to have played itself out in Oran, eliciting shouts of joy and celebration from the general population, the narrator, Dr Rieux, sounds a note of caution (Camus 1991):

He knew what those jubilant crowds did not know but could have learned from books: that the plague bacillus never dies or disappears for good; that it can lie dormant for years and years in furniture and linen chests; that it bides its time in bedrooms, cellars, trunks, and bookshelves; and that perhaps the day would come when, for the bane and the enlightening of men, it would rouse up its rats again and send them forth to die in a happy city. (p. 308)

Pestilence will never be completely eradicated. Suffering will never be eradicated. Did Christ not say that poverty (the poor) will always be with us? ${ }^{7}$ The absurdity of life underlies our very existence, popping out its head from time to time, causing tremendous misery and suffering. It is not a divine judgement; it is not purely the fault of erroneous human logic. There is no causal or determinative meaning attached to it, and hence, there is neither a metaphysical explanation nor telos associated with it. It is what it is. It unfolds as it unfolds. The best theological response we can offer is to 7.Matthew 26:11, perhaps reflecting on the teaching of Deuteronomy 15:11. 
lament, to try and explain, and to respond, with God, in participatory love.

\section{Acknowledgements Competing interests}

The author declares that he has no financial or personal relationship(s), which may have inappropriately influenced him in writing this article.

\section{Author's contribution}

W.B. is the sole author of this article.

\section{Ethical consideration}

This article followed all ethical standards for a research without direct contact with human or animal subjects.

\section{Funding information}

This research received no specific grant from any funding agency in the public, commercial or not-for-profit sectors.

\section{Data availability statement}

Data sharing is not applicable to this article as no new data were created or analysed in this study.

\section{Disclaimer}

The views and opinions expressed in this article are those of the author and do not necessarily reflect the official policy or position of any affiliated agency of the author.

\section{References}

Abraham, W.J., 2017, Among the ashes: On death, grief, and hope, Wm. B. Eerdmans, Grand Rapids, MI.

Ballard, P., 1975, 'Camus and Bonhoeffer: Living in a Godless world', Theology $78,418-428$.

Camus, A., 1950, Actuelles: Chroniques 1944-1948, Gallimard, Paris.

Camus, A., 1991, The plague, transl. S. Gilbert, Vintage, New York, NY.

Camus, A., 1992, The rebel, transl. A. Bower, Vintage, New York, NY.

Citizen Reporter (Anonymous), 2020, 'Bushiri says demonic COVID-19 is only targeting certain people', The Citizen, viewed 30 April 2020, from https://citizen.co.za/ news/south-africa/general/2262220/bushiri-says-demonic-covid-19-is-onlytargeting-certain-people.

Copeland, K., 2020a, Judgment is executed on COVID-19, viewed 30 April 2020, from https://www.youtube.com/watch?v=OSIrQBGfUtw.

Copeland, K., 2020b, Kenneth Copeland prophecy: 'COVID-19 will be over much sooner than you think', viewed 30 April 2020, from https://www.youtube.com/ watch? $v=$ Ys 3 CrUdxSGM.

Kettley, S., 2020, 'Bible verses about coronavirus: What does the Bible say about COVID-19?', Express, viewed 30 April 2020, from https://www.express.co.uk/ news/weird/1260571/Bible-verses-coronavirus-what-Bible-say-COVID19-latestnews.

Ledwith, M., 1976, 'God's face in evil', The Furrow 29(7), 664-670.

McWilliams, S., 1990, Sainthood in Albert Camus' The plague and Thomas Merton's Faith and violence, Abe Books, Victoria.

Monasterio, X., 1999, 'Camus' meditation on the Christian faith', Horizons 26(2), 215-231. https://doi.org/10.1017/S0360966900031923

Mudde, C., 2020, 'The anti-lockdown protests are about more than just quarantines', The Guardian, viewed 21 April, from https://www.theguardian.com/us-news/ commentisfree/2020/apr/21/anti-lockdown-protests-trump-right-wing.

Oord, T.J., 2019, God can't: How to believe in God and love after tragedy, abuse, and other evils, SacraSage Press, Grasmere.

Oord, T.J., 2020, We can lament and explain, viewed 05 May 2020, from http:// thomasjayoord.com/index.php/blog/archives/we-can-lament-and-explain.

Sharpe, M., 2014, 'The black side of the sun', Political Theology 15(2), 151-174. https://doi.org/10.1179/1462317X13Z.00000000072

Whistler, G., 2018, 'Saints without God: Camus' poetics of secular faith', Nordisk Judaistik 49(1), 49-61.

Wilson, J., 2020, 'The rightwing Christian preachers in deep denial over COVID-19's danger', The Guardian, viewed 30 April 2020, from https://www.theguardian. com/us-news/2020/apr/04/america-rightwing-christian-preachers-virus-hoax.

Wright, N.T., 2020, 'Christianity offers no answers about the coronavirus', Time, viewed 06 April 2020, from https://time.com/5808495/coronavirus-christianity/. 